\title{
PROGRAM CORPORATE SOCIAL RESPONSIBILITY (CSR) DAN STRATEGINYA UNTUK PENINGKATAN KEPUASAN MASYARAKAT SERTA DAMPAK SOSIAL EKONOMI MASYARAKAT
}

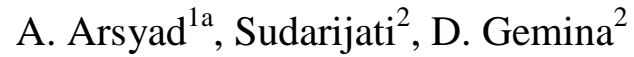 \\ ${ }^{1)}$ Fakultas Pertanian Universitas Djuanda Bogor \\ ${ }^{2)}$ Fakultas Ekonomi Universitas Djuanda Bogor \\ ${ }^{a}$ Korespondensi: Apendi Arsyad, Telp: 08129347542, Email: apendi.arsyad@yahoo.com; \\ atikmartono@gmail.com; dwigemina@gmail.com;
}

\begin{abstract}
The purpose of this research was to determine the effect of the perception and satisfaction of the community to CSR and its impact on socioeconomic in Bogor regency. Questionnaire were distributed to 250 respondents . Likert scale was used prior to testing with multiple regression. The results showed that the implementation of CSR programs in Bogor has been done quite effectively. Perception and satisfaction of the community have an influence simultaneously and partially on CSR. The CSR activities in education, health, environment, increasing of desire and basic human needs and security simultaneously have influences towards the socio-economic communities. Partially, education has no effect on socioeconomic condition. The implementation strategy of using Importance Performance Analysis ( IPA ). The strategies which have been generated are 1 ) making ongoing improvements so that the performance attributes ( CSR programs expectancy) will be increased ; 2 ) maintaining so that the performance will not be declined; 3 ) should be managed seriously because community usually can lead to a disappointment ; 4 ) evaluating all activities
\end{abstract}

Keywords : CSR program, Community Satisfaction, Social Economic of the community

\begin{abstract}
ABSTRAK
Tujuan penelitian untuk menentukan pengaruh persepsi dan kepuasan masyarakat terhadap CSR dan dampaknya terhadap sosial ekonomi di Kabupaten Bogor. Koesioner didistribusikan kepada 250 responden. Skala likert digunakan sebelum dilakukan pengujian dengan regresi berganda. Hasil penelitian menunjukkan bahwa implementasi program CSR perusahaan di Kabupaten Bogor sudah cukup efektif. Persepsi dan kepuasan masyarakat mempunyai pengaruh secara simultan dan parsial terhadap CSR. Adapun kegiatan CSR bidang pendidikan, kesehatan, lingkungan, kenaikan keinginan dan kebutuhan dasar manusia serta keamanan mempunyai pengaruh secara simultan terhadap sosial ekonomi masyarakat. Sedangkan secara parsial pendidikan tidak mempunyai pengaruh terhadap sosial ekonomi masyarakat. Penerapan strategi menggunakan importance performance analysis (IPA). Strategi adalah 1) melakukan perbaikan secara terus-menerus sehingga performance atribut (harapan program CSR) meningkat; 2) mempertahankan agar tidak menurun kinerjanya; 3) harus dikelola dengan serius karena biasanya menimbulkan kekecewaan masyarakat; dan 4) mengevaluasi seluruh kegiatan
\end{abstract}

Kata Kunci : Program CSR, Kepuasan Masyarakat, Sosial Ekonomi Masyarakat 


\section{PENDAHULUAN}

Perubahan struktur ekonomi di Indonesia telah mendorong perubahan pola kehidupan masyarakat Indonesia dari masyarakat agraris menjadi masyarakat industri. Hal ini ditandai dengan munculnya berbagai jenis perusahaan (coorporasi) yang bergerak dalam berbagai bidang dan sektor, baik di bidang pertambangan, manufaktur, otomotif, dan lain-lain. Proses industri tersebut tidak hanya menghasilkan dampak secara ekonomi dan pembangunan, namun juga memberikan dampak pada masyarakat lokal (local community) yang merasakan operasionalisasi perusahaan secara langsung. Di sisi lain, kegiatan industri juga menghasilkan berbagai konsekuensi, seperti dihasilkannya limbah industri, eksploitasi sumber daya alam komunitas lokal, peningkatan polusi, dan lain sebagainya. Sebagai tanggung jawab atas manfaat ekonomi yang telah diambil oleh industri dengan mengorbankan sumber daya komunitas lokal, maka muncul konsep kepedulian sosial masyarakat berupa program corporate social responsibility (CSR). Mengenai CSR, Howard R. Bowen dalam Dody P (2008) mengemukakan bahwa keberhasilan dunia bisnis ditentukan oleh bagaimana kontribusinya terhadap kesejahteraan masyarakat umum, bukan semata untuk warga bisnis itu sendiri.

$$
\text { Program CSR dalam }
$$

perkembangannya juga mengacu kepada terwujudnya salah satu tujuan pembangunan Milenium (Millenium Development Goals/MDGs) yaitu mengentaskan kemiskinan. Oleh karena itu, program CSR mendapat perhatian pada tatanan internasional terutama dikaitkan dengan isu peningkatan kesejahteraan masyarakat dunia dan kepedulian terhadap pemanasan global. Studi terkait dengan 50 perusahaan di 7 (tujuh) negara Asia, menyimpulkan bahwa penetrasi pelaksanaan CSR dan derajat komunitasnya di Indonesia tercatat paling rendah dibanding negara lain seperti India,
Korea Selatan, Thailand, Singapura, Malaysia dan Filippina (Chapple W \& Moon J (2005).

Di Indonesia program CSR semakin menguat untuk diimplementasi atas dasr hukum berdasarkan UndangUndang (UU) Nomor 40 Tahun 2007 tentang Perseroan Terbatas pada Bab V Pasal 74, dan masih menimbulkan kontrovesial, karena kebijakan mewajibkan aktivitas CSR hanya untuk perusahaan tambang saja. Konsep CSR yang berkembang selama ini lebih dominan pada proses pemberdayaan lingkungan sosial yang bersifat jangka pendek ketimbang jangka panjang. Pembinaan sumber daya manusia (SDM) seringkali lebih berorientasi pada kelompok masyarakat tertentu, sehingga jangkauan manfaat menjadi kurang luas dan tidak berkelanjutan. Oleh sebab itu, agar implementasi program CSR lebih efektif dan memberikan nilai manfaat, maka pengembangan program CSR pada masa akan datang perlu lebih berorientasi pada peningkatan kemandirian masyarakat untuk secara kreatif menggali potensi sumberdaya yang ada pada lingkungan sekitarnya, melalui desain kemitraan strategis antar beberapa pihak. Sehubungan dengan hal tersebut, sangat penting untuk mengetahui pengaruh persepsi dan kepuasan masyarakat terhadap program CSR, serta pengaruh program CSR terhadap aspek sosial ekonomi masyarakat, dan sejauhmana efektifitas implementasi dari programprogram CSR yang telah diberikan perusahaan di lapangan.

\section{LANDASAN TEORI DAN HIPOTESIS}

Robbins (2006) mengemukakan persepsi sebagai suatu proses dimana individu - individu mengorganisasikan dan menafsirkan kesan indera mereka agar memberi makna kepada lingkungan. Sedangkan persepsi menurut Kotler (2000) merupakan proses yang digunakan individu untuk memilih, mengorganisasi dan mengintepretasikan masukan-masukan 
informasi guna menciptakan gambaran dunia yang memiliki arti. Faktor-faktor yang mempengaruhi persepsi adalah attitudes, motivation, interest, experiences dan ekspectation (Kotler, 2000).

Dalam era globalisasi dengan tingkat persaingan yang ketat, banyaknya produk atau jasa yang sejenis, membuat konsumen memiliki banyak pilihan untuk memuaskan kebutuhannya. Dengan demikian, strategi pemasaran yang berbasis konsumen dapat menjadi alternative untuk memenangkan persaingan (Sutisna, 2003). Menurut Oliver dalam Supranto (2001) bahwa kepuasan sebagai tingkat perasaan seseorang setelah membandingkan kinerja atau hasil yang dirasakan dengan harapannya. Sedangkan menurut Day dalam Tjiptono (2001), kepuasan atau ketidakpuasan merupakan respon pelanggan terhadap evaluasi ketidaksesuaian (disconfirmation) yang dirasakan antara harapan sebelumnya (atau norma kinerja lainnya) dan kinerja aktual produk yang dirasakan setelah pemakaiannya. Selanjutnya Rangkuti (2003) menyatakan kepuasan adalah respon pelanggan terhadap ketidaksesuaian antara tingkat kepentingan sebelumnya dan kinerja aktual yang dirasakannya setelah pemakaian. Sehingga kepuasan merupakan perasaan senang, puas individu karena antara harapan dan kenyataan dalam memakai dan pelayanan yang diberikan terpenuhi. Menurut Kotler dalam Alma (2003) bahwa kepuasan konsumen terdiri dari situasional factors dan personal factor.

International Standard of Organization (ISO) 26000 mengenai Guidance on Social Responsibility memberikan definisi CSR dalam Jajal \& Kurniawan, Fajar (2012), yaitu sebagai berikut: "Tanggung jawab sebuah organisasi terhadap dampak-dampak dari keputusan-keputusan dan kegiatankegiatannya pada masyarakat dan lingkungan yang diwujudkan dalam bentuk perilaku transparan dan etis yang sejalan dengan pembangunan berkelanjutan dan kesejahteraan masyarakat; mempertimbangkan harapan pemangku kepentingan, sejalan dengan faktor yang ditetapkan dan norma-norma perilaku internasional; serta terintegrasi dengan organisasi secara menyeluruh". Sedangkan The World Business Council for Sustainable Development mendefinisikan CSR sebagai suatu komitmen bisnis untuk berkontribusi dalam pembangunan ekonomi berkelanjutan, bekerja dengan karyawan perusahaan, keluarga karyawan tersebut, berikut komunitas setempat (local) dan masyarakat secara keseluruhan dalam rangka meningkatkan kualitas hidup (Reza Rahman, 2009).

Kotler \& Lee (2005) mengemukakan CSR merupakan suatu komitmen untuk meningkatkan kesejahteraan masyarakat melalui kebebasan praktik bisnis dan kontribusi dari sumber daya perusahaan. Dari berbagai definisi tersebut, maka CSR bukan semata-mata kegiatan atau pembangunan ekonomi, lingkungan, dan profit perusahaan, tetapi lebih jauh harus terintegrasi dalam faktor dan norma yang berlaku.

Adapun kegiatan CSR mencakup : 1) Building human capital. Berkaitan dengan internal perusahaan untuk menciptakan sumber daya manusia yang andal, di sisi lain perusahaan juga dituntut melakukan pemberdayaan masyarakat; 2) Strengtening economies. Perusahaan harus memberdayakan ekonomi masyarakat sekitarnya, agar terjadi pemerataan kesejahteraan; 3) Assesing social chesion. Upaya menjaga keharmonisan dengan masyarakat sekitar, agar tidak menimbulkan konflik; 4) Encouraging good governance. Perusahaan dalam menjalankan bisnisnya mengacu pada Good Corporate Governance (GCG); 5) Protecting the environment. Mengharuskan perusahaan untuk menjaga lingkungan sekitarnya (Wahyudi \& Azheri, 2008). Kotler \& Lee (2005) 
mengkategorikan beberapa inisiatif dalam program CSR, antara lain dikontribusikan untuk: 1) Kesehatan Komunitas: pencegahan AIDS, deteksi awal untuk kanker payudara, imunisasi rutin; 2) Keselamatan: membuat program pengendara, pencegahan, pembatasan penggunaan keselamatan mobil; 3) Pendidikan: pemberantasan buta huruf, pendidikan untuk sekolah, pendidikan berkebutuhan khusus; 4) Karyawan: pelatihan kerja, praktik perekrutan, lokasi pabrik; 5) Lingkungan: daur ulang, mengurangi penggunaan bahan kimia berbahaya, mengurangi kemasan; 6) Pembangunan ekonomi dan komunitas: peminjaman bunga perumahan yang rendah; 7) Keinginan dan kebutuhan dasar manusia: kelaparan, tuna wisma, hak-hak hewan, hak suara, upaya anti diskriminasi, dan lain-lain.

\section{Menurut Badan Koordinasi}

Keluarga Berencana Nasional (BKKBN), kemiskinan dapat diartikan sebagai situasi dimana penduduk hanya dapat memenuhi kebutuhan makan, pakaian dan perumahan dalam tingkat minimum yang sangat diperlukan untuk sekedar hidup. Sedangkan menurut BAPPENAS (2004), kemiskinan merupakan kondisi di mana seseorang atau sekelompok orang, laki-laki dan perempuan, tidak memenuhi hak-hak dasarnya untuk mempertahankan dan mengembangkan kehidupan yang bermartabat, antara lain, terpenuhinya kebutuhan pangan, kesehatan, pendidikan, pekerjaan, perumahan, air bersih, pertanahan, sumberdaya alam, dan lingkungan hidup, rasa aman dari perlakuan atau ancaman tindak kekerasan dan hak untuk berpartisipasi dalam kehidupan sosial-politik, baik bagi perempuan maupun laki-laki.

Masalah kesenjangan dapat ditinjau dari tiga aspek, yaitu kesenjangan antar golongan penduduk, kesenjangan antar sektor, dan kesenjangan antar daerah. Pemahaman terhadap masalah ketidakmerataan antar golongan penduduk dapat dilakukan dengan melihat pergeseran distribusi pendapatan. Untuk itu langkah penting untuk mengurangi kesenjangan pendapatan antar golongan penduduk adalah meningkatkan produktivitas dan pendapatan kelompok masyarakat berpendapatan rendah, melalui program-program pemberdayaan ekonomi rakyat.

Kondisi ekonomi umumnya dilihat dari tingkat pendapatan masyarakat,menurut Mubyarto dalam Rosika (2011), pendapatan merupakan penerimaan yang dikurangi dengan biayabiaya yang dikeluarkan. Selanjutnya Rosika (2011) mengutip penjelasan mengenai pendapatan menurut Badan Pusat Statistik (BPS), yaitu perhitungan pendapatan dapat dilakukan dengan menggunakan pengeluaran atau konsumsi masyarakat. Hal ini didasari oleh paradigma bahwa bila pendapatan mengalami kenaikan maka akan diikuti oleh berbagai kebutuhan yang semakin banyak sehingga menuntut pengeluaran yang tinggi pula.

Dalam rangka meningkatkan kesejahteraan masyarakat, program CSR umumnya dilaksanakan dalam bentuk pemberdayaan masyarakat yang dirancang dengan strategi yang tepat agar dapat menyentuh segala permasalahan sesuai dengan kebutuhan masyarakat. Keberhasilan program CSR yang telah dilaksanakan perusahaan diharapkan dapat mempengaruhi kondisi sosial ekonomi masyarakat yang mengikuti program CSR. Hal tersebut akan sangat membantu masyarakat dalam memperbaiki kondisi perekonomiannya. Indikator keberhasilan program CSR tersebut sejalan dengan indikator yang akan digunakan dalam mengukur kondisi sosial ekonomi masyarakat di desa binaan PT. Indocement, PT. Holcim dan PT. Aneka Tambang. Sehingga semakin tinggi tingkat keberhasilan program CSR yang diinisiasikan suatu perusahaan maka semakin baik kondisi sosial ekonomi masyarakat desa binaan perusahaan tersebut. Bertitik tolak dari seluruh 
landasan teori tersebut, maka dirumuskan paradigma pengaruh persepsi dan kepuasan masyarakat terhadap CSR dan dampaknya terhadap sosial ekonomi masyarakat di Kabupaten Bogor. Secara garis besar dapat digambarkan bagan alur kerangka pikiran yang dapat dilihat pada Gambar 1 berikut.

\section{Hipotesis}

Untuk memberikan arah pada penelitian ini, digunakan beberapa hipotesis sebagai berikut:

1. Persepsi dan kepuasan masyarakat mempunyai pengaruh terhadap program kepedulian sosial perusahaan (CSR)
2. Semakin tepat kegunaan dan harapan masyarakat untuk mengalami kepuasan, maka semakin tepat pelaksanaan program CSR;

3. Pelaksanaan program CSR melalui pendidikan, kesehatan, lingkungan, keinginan dan kebutuhan dasar manusia, pembangunan ekonomi dan komunitas, keselamatan mempunyai pengaruh terhadap sosial ekonomi masyarakat; dan

4. Semakin tepat pelaksanaan program kepedulian CSR maka adanya peningkatan taraf hidup masyarakat.

Alur kerangka berpikir dari penelitian ini disajikan pada Gambar 1 berikut ini:

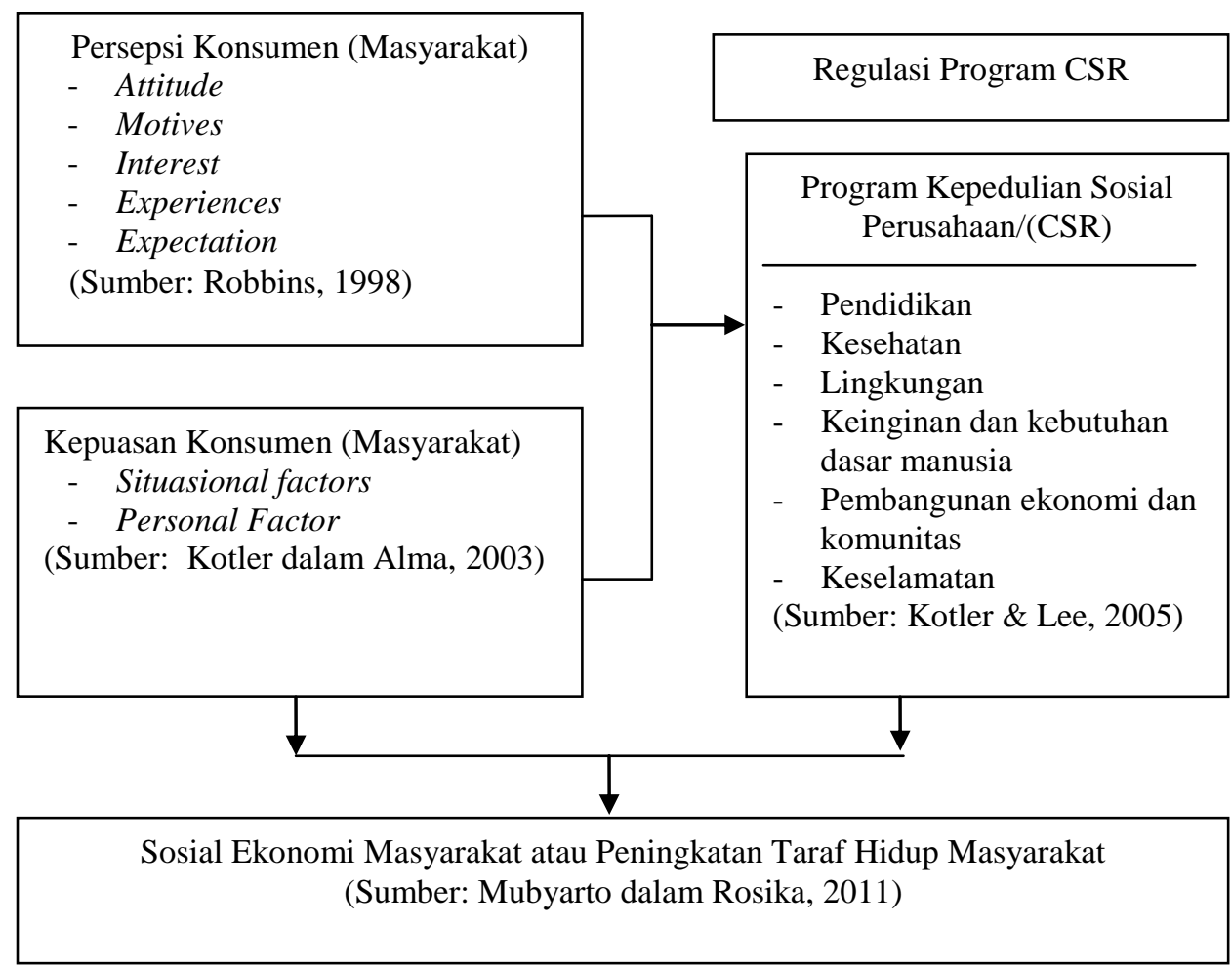

Gambar 1. Bagan Alur Kerangka Pikiran

\section{METODE PENELITIAN}

Bentuk penelitian yang digunakan adalah verikatif melalui pengumpulan data di lapangan untuk menguji hipotesis dengan perhitungan statistik (M. Nasir, 2003). Metode penelitian yang digunakan adalah metode survey. Objek dalam penelitian ini adalah masyarakat yang terlibat dalam program CSR perusahaan di Kabupaten Bogor, yang terdiri dari: CSR PT Indocement, PT Holcim dan CSR PT Aneka Tambang (PT. Antam). Jenis data primer diperoleh dengan metode wawancara dan menggunakan kuesioner terstruktur yang diberikan kepada masyarakat yang menjadi responden terpilih. Sedangkan data sekunder didapat dengan menelaah data yang diperoleh dari 
bagian administrasi laporan dan publikasi ilmiah yang telah diterbitkan.

Untuk menjawab permasalahan, variabel yang akan dianalisis dalam penelitian ini terdiri dari variabel bebas, yaitu persepsi masyarakat $\left(\mathrm{X}_{1}\right)$ meliputi attitudes, motives, interests, experience, expectation; kepuasaan masyarakat $\left(\mathrm{X}_{2}\right)$ meliputi situasional factors, personal factors dan variabel terikat yaitu CSR (Y) untuk persamaan pertama. Sedangkan persamaan kedua variabel bebas CSR meliputi kesehatan, pendidikan, lingkungan, keinginan dan kebutuhan dasar manusia serta keamanan. Sedangkan variabel terikatnya adalah sosial ekonomi masyarakat atau peningkatan taraf hidup masyarakat $(\mathrm{Z})$.

Skala pengukuran dalam data yang dikumpulkan masih skala ordinal. Menurut Riduwan (2005) \& Sunarto (2009), sebelum dilakukan pengujian dengan regresi berganda, perlu terlebih dahulu menggunakan skala pengukuran yaitu skala Likert (1-5). Suatu alat ukur dianggap sahih, apabila tingkat ketelitian dan ketepatan mengukur apa yang diukur. Dengan demikian, kesahihan sangat berkaitan dengan ketepatan hasil pengukuran suatu alat. Keandalan suatu alat ukur dapat diuji dengan skor yang dihasilkan relatif sama pada seorang responden, walaupun responden tersebut mengerjakannya dalam waktu yang berbeda. Jadi keandalan suatu alat ukur berkaitan dengan konsistensi pengukurannya

Adapun populasi dalam penelitian ini adalah masyarakat yang terlibat dalam program CSR yang dilaksanakan oleh 3 (tiga) perusahaan di 3 (tiga) kecamatan yang ada di Kabupaten Bogor, yaitu: 1) Kecamatan Citeureup (PT. Indocement) terdiri Desa Cietereup, Desa Gunung Sari, Desa Hambalang, Desa Pasir Mukti, Kelurahan Puspanegara, Desa Tajur dan Desa Tarikolot; 2) Kecamatan Klapanunggal (PT. Holcim) terdiri Desa Nambo, Desa Bantar Jati, Desa Lulut; 3) Kecamatan Nanggung (PT. Aneka
Tambang) terdiri Desa Bantar Karet, Desa Pangkal Pangkal Jaya, Desa Parakan Muncang dan Desa Kalong Liud. Sedangkan desa-desa yang dipilih adalah desa-desa yang berbatasan langsung dengan lokasi perusahaan. Desa terpilih berjumlah sebanyak 14 desa dengan jumlah sampel yang digunakan sebanyak 250 orang.

Menurut Husein Umar (2008) untuk menentukan ukuran sampel suatu populasi atau jumlah responden yang akan dijadikan sampel pada masyarakat, maka teknik penentuan sampel yang dianggap representatif digunakan adalah dengan menggunakan rumus Slovin. Selanjutnya menurut Riduwan (2005) bahwa jumlah sampel yang akan diambil sebagai responden dapat diperoleh dengan menggunakan Strattified Random Sampling (SRS) jumlah sampel masingmasing desa terpilih.

\section{Uji Asumsi Klasik}

Menurut Agung Abdul Rasul \& Nurlelah (2010) asumsi klasik adalah beberapa asumsi yang mendasari validitas analisis regresi linier berganda. Asumsi klasik terdiri dari beberapa hal meliputi asumsi normalitas, asumsi tidak ada gejala multikolieritas dan autokolerasi, dan asumsi homoskedastisitas. Jika regresi linier berganda memenuhi beberapa asumsi tersebut maka merupakan regresi yang baik.

\section{Metode Analisis}

Analisis data secara deskriptif dan verifikatif dengan menggunakan uji statistik. Persamaan umum regresi linear sederhana untuk model penelitian -1 berikut ini:

$\mathrm{Y}=\mathrm{a}+\mathrm{b}_{1} \mathrm{X}_{1}+\mathrm{b}_{2} \mathrm{X}_{2}+\varepsilon$

dimana :

$\mathrm{Y}=$ Tanggung jawab sosial perusahaan/CSR; $\mathrm{a}=$ Nilai konstanta; $\mathrm{b}=$ Angka arah atau koefisien regresi, yang menunjukkan angka peningkatan ataupun penurunan variabel dependen yang 
didasarkan pada perubahan variabel independen; $\mathrm{X}_{1}=$ Nilai persepsi konsumen/masyarakat; $\quad \mathrm{X}_{2}=$ Nilai kepuasan konsumen/masyarakat; $\varepsilon=$ faktor lain yang tidak diteliti

Untuk mengetahui pengaruh antar-variabel CSR terhadap sosial ekonomi masyarakat, persamaan regresi model penelitian -2 berikut ini:

$\mathrm{Z}=\mathrm{a}+\mathrm{b}_{1} \mathrm{Y}_{1}+\mathrm{b}_{2} \mathrm{Y}_{2}+\mathrm{b}_{3} \mathrm{Y}_{3}+\mathrm{b}_{4} \mathrm{Y}_{4}+\mathrm{b}_{5} \mathrm{Y}_{5}+\varepsilon$

dimana:

$\mathrm{Z}=$ Sosial ekonomi masyarakat; $\mathrm{a}=$ nilai konstanta; $\mathrm{b}=$ Angka arah atau koefisien regresi, yang menunjukan angka peningkatan ataupun penurunan variabel dependen yang didasarkan pada perubahan variabel independen; $\mathrm{Y}_{1}=$ Nilai kesehatan; $\mathrm{Y}_{2}=$ Nilai pendidikan; $\mathrm{Y}_{3}=$ Nilai lingkungan; $\mathrm{Y}_{4}=$ Nilai keinginan dan kebutuhan dasar manusia; $\mathrm{Y}_{5}=$ Nilai keamanan; $\varepsilon=$ faktor lain yang tidak diteliti

Untuk menguji hipotesis penelitian yang diajukan akan digunakan uji statistik dengan model penelitian pertama sebagaimana Gambar 2 berikut ini.

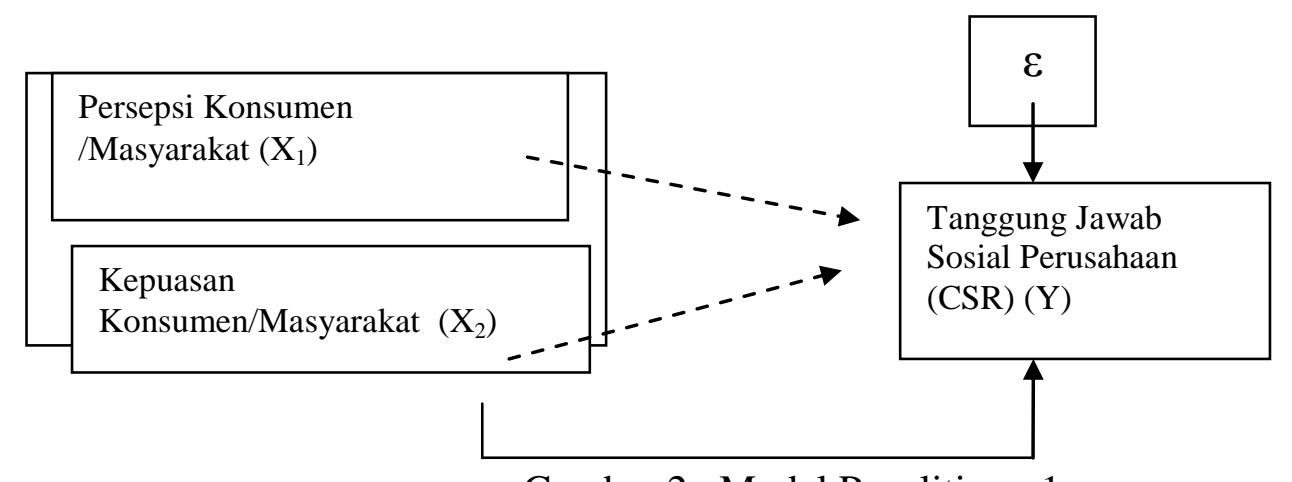

Gambar 2. Model Penelitian - 1

Keterangan $: \varepsilon=$ Variabel Error $;-----\bullet=$ Pengaruh Parsial; $\longrightarrow=$ Pengaruh Simultan

Sedang model penelitian kedua disajikan pada Gambar 3 berikut ini:

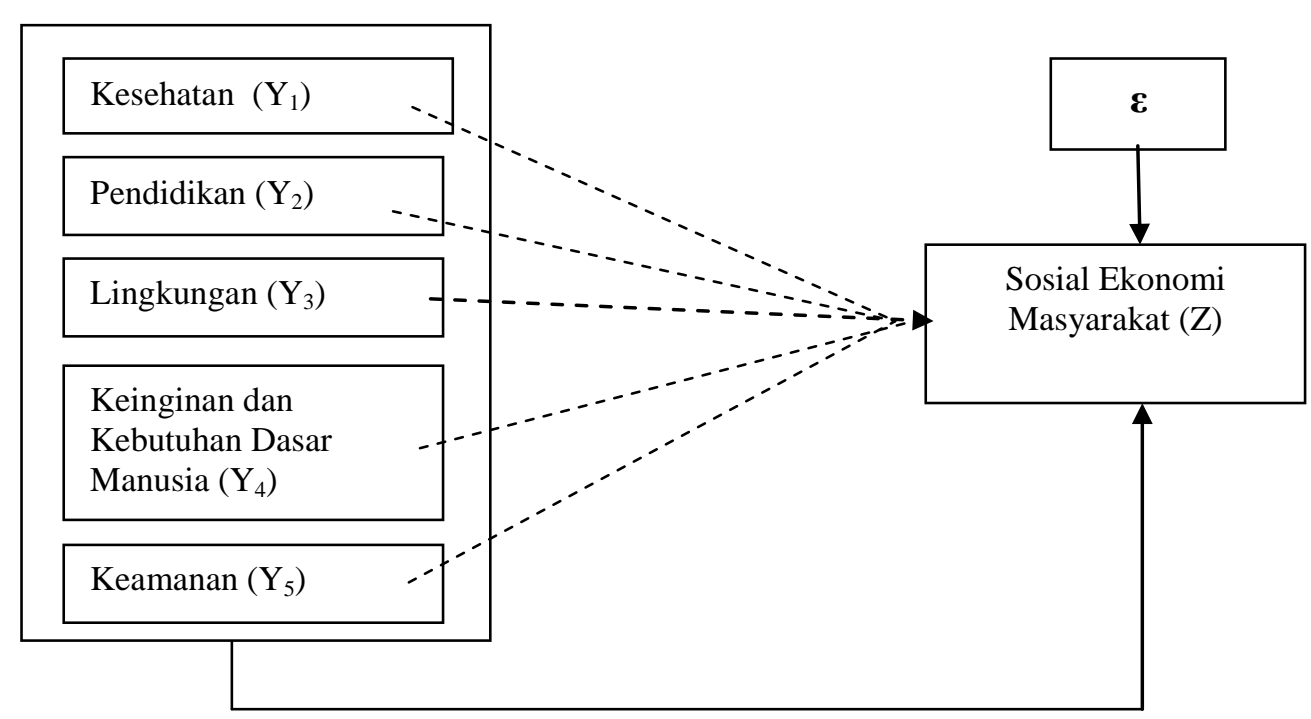

Gambar 3. Model Penelitian - 2

Keterangan $: \varepsilon=$ Variabel Error $;---->=$ Pengaruh Parsial; $\longrightarrow=$ Pengaruh Simultan 


\section{Pengujian Hipotesis}

Untuk mengetahui pengaruh secara simultan variabel independen digunakan uji $\mathrm{F}$ (F-test) dengan tingkat signifikansi $(\alpha)=0,05$ yang dapat membuktikan secara statistik bahwa keseluruhan koefisien regresi signifikan dalam dalam mempengaruhi variabel dependen. Bila semua nilai parameter regresi sama dengan nol dapat disimpulkan bahwa tidak terdapat hubungan yang linier antara variabel dependen dengan variabel independen (Sudjana,1996).

Hipotesis operasionalnya:

$$
\begin{aligned}
& \mathrm{H}_{0}: \beta_{\mathrm{i}}=0, \mathrm{i}=1,2 \ldots 5 ; \\
& \mathrm{H}_{1}: \beta_{\mathrm{i}} \neq 0,
\end{aligned}
$$

Paling tidak ada salah satu koefisien regresi yang tidak sama dengan nol. Untuk mengetahui pengaruh faktor lain digunakan rumus: $1-R^{2}$. Keputusan:

$\mathrm{F}>\mathrm{F}_{\alpha}\{\mathrm{k} ;(\mathrm{n}-\mathrm{k}-\mathrm{l})\}$, maka tolak $\mathrm{H}_{0}$. $\mathrm{F}_{\leq} \mathrm{F}_{\alpha}\{\mathrm{k} ;(\mathrm{n}-\mathrm{k}-1)\}$, maka terima $\mathrm{H}_{0}$.

Untuk mengetahui pengaruh secara parsial variabel independen digunakan uji t $(t$-test $)$ dengan tingkat signifikansi $(\alpha)=$ 0,05

Hipotesis Operasional:

$$
\begin{aligned}
& \mathrm{H}_{0}: \beta_{\mathrm{i}}=0 \\
& \mathrm{H}_{1}: \beta_{\mathrm{i}} \neq 0
\end{aligned}
$$

Keputusan:

$t_{i}>t_{(\alpha, n-2)}$, maka tolak $H_{0} ; \quad t_{i}>t_{(\alpha, n-5)}$, maka tolak $\mathrm{H}_{0}$

$\mathrm{t}_{\mathrm{i}} \leq \mathrm{t}_{(\alpha, \mathrm{n}-2)}$, maka terima $\mathrm{H}_{0} ; \mathrm{t}_{\mathrm{i}} \leq \mathrm{t}_{(\alpha, n-5)}$, maka terima $\mathrm{H}_{0}$

Sedangkan untuk mengetahui akibat mana yang harus diberi prioritas lebih dibandingkan dengan atribut lainnya, maka digunakan Importance Performance Analysis (IPA) atau analisis tingkat kepentingan dan evaluasi atau kinerja. Menurut J. Supranto (2000), untuk menentukan prioritas faktor persepsi masyarakat digunakan rumus untuk mencari rata-rata penilaian kinerja dan tingkat kepentingan (harapan) masyarakat atau responden, dengan menggunakan rumus sebagai berikut:

$$
\bar{Y}=\frac{\sum Y i}{n} \quad \bar{X}=\frac{\sum Y i}{n}
$$

dimana:

$\bar{Y}=$ Skor rata-rata nilai kepentingan masyarakat; $\bar{X}=$ Skor rata-rata persepsi Masyarakat;

dan $\mathrm{n}=$ Jumlah responden

Hasil rata-rata tersebut kemudian dirata-ratakan kembali untuk mengetahui posisi masing-masing atribut pada perceptual mapping IPA (Important Performance Analysis), dengan menggunakan rumus dari J.Supranto (2000) sebagai berikut :

$$
\overline{\bar{Y}}=\frac{\sum Y i}{n} \quad \overline{\bar{X}}=\frac{\sum Y i}{n}
$$

dimana:

$\overline{\bar{Y}}=$ Skor rata-rata kepentingan masyarakat

$\overline{\bar{X}}=$ Skor rata-rata persepsi masyarakat;

$\mathrm{n}=$ Jumlah responden

Untuk memperluas analisis, maka digunakan perceptual mapping IPA (Important Performance Analysis) yang memiliki empat prioritas (empat kuadran) penilaian berdasarkan penilaian kinerja dan tingkat kepentingan di mata masyarakat program CSR sebagamana Gambar 4. Sebagaimana Gambar 4 interpretasi grafik IPA, Prioritas utama (kuadran A), menunjukkan kinerja yang dianggap mempengaruhi kepuasan, termasuk unsur persepsi masyarakat yang dianggap penting oleh masyarakat, namun program CSR dianggap belum melaksanakan sesuai dengan keinginan masyarakat, yang mengakibatkan masyarakat merasa kecewa. Prioritas prestasi (kuadran B), menunjukkan kinerja yang telah berhasil dilaksanakan oleh program CSR untuk wajib dipertahankan dan dianggap sangat penting dan memuaskan oleh masyarakat. Prioritas rendah (kuadran $\mathrm{C}$ ), menunjukkan faktor persepsi masyarakat yang diberikan oleh program CSR kurang penting bagi masyarakat dan kinerja program CSR dinilai kurang baik oleh masyarakat. 
Prioritas berlebihan (kuadran D), menunjukkan faktor persepsi masyarakat yang dianggap kurang penting oleh

masyarakat, namun kinerja yang diberikan program CSR memuaskan masyarakat.

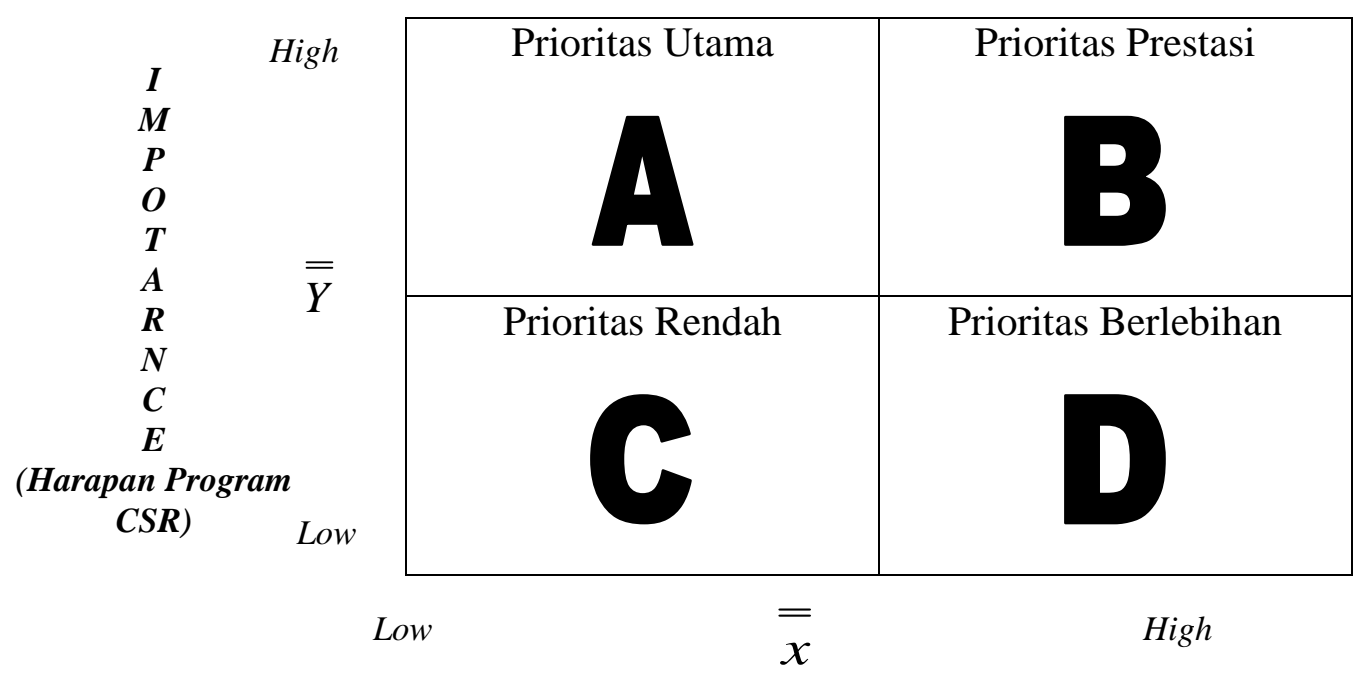

PERFORMANCE (Penilaian Program CSR)

Sumber: Darmadi Durianto, dkk (2001)

Gambar 4. Pembagian Kuadran Importance-Performance Analysis (IPA)

\section{HASIL DAN PEMBAHASAN}

\section{Analisis Validitas dan Reliabilitas Instrumen Penelitian}

Menurut Saifuddin Azwar (1997), dalam uji validitas koesioner item-item pertanyaan dikatakan valid, bila item tersebut memiliki korelasi dengan total variabel di atas 0,3 , sedangkan item yang memiliki korelasi di bawah 0,3 dikategorikan tidak valid dan akan disisihkan dari analisis selanjutnya. Menurut Arikunto (2006) bahwa hasil pengujian reliabilitas menunjukkan seberapa jauh suatu alat ukur dapat dipercaya atau diandalkan melalui pengujian validitas dan dinyatakan valid, untuk uji reliabilitas digunakan teknik Alpha Cronbach, di mana suatu instrumen dapat dikatakan handal (reliabel) apabila memiliki koefisien keandalan atau Alpha sebesar 0,6 atau lebih dan uji reliabilitas menunjukkan koesioner reliabel.

\section{Rata-rata Tanggapan Responden terhadap Variabel Penelitian \\ Rata-rata tanggapan responden} terhadap persepsi masyarakat sebesar 3,48 ini berarti bahwa masyarakat setuju bahwa kegiatan CSR merupakan bentuk perhatian/kepedulian perusahaan kepada masyarakat, pelaksanaannya sudah bersinergi dengan program pemerintah daerah kabupaten, dan telah mendorong pemberdayaan masyarakat sekitar.

Kegiatan CSR sudah dilaksanakan dengan baik dan bermanfaat bagi masyarakat sekitar perusahaan. Sedangkan rata-rata tanggapan responden terhadap kepuasan masyarakat sebesar 3,39 ini dapat diartikan bahwa masyarakat di sekitar perusahaan merasakan kepuasan dengan tingkat memuaskan terhadap pelaksanaan program CSR perusahaan.

Dengan demikian, perbandingan antara harapan yang dimiliki oleh masyarakat dengan kenyataan yang diterima oleh masyarakat pada saat implementasi program CSR relatif sama 
sehingga memuaskan masyarakat. Ratarata tanggapan responden terhadap CSR sebesar 3,36 atau cukup baik. Hal ini menunjukkan bahwa semua bidang dalam program CSR, yaitu: pendidikan, kesehatan, ekonomi, lingkungan, sosial, dan keamanan sudah diimplementasikan dengan cukup baik. Rata-rata penilaian responden terhadap sosial ekonomi masyarakat sebesar 3,40. Hal ini menggambarkan bahwa dampak CSR terhadap kondisi sosial ekonomi masyarakat cukup baik. Kondisi ini disebabkan oleh keberhasilan pembangunan khususnya pembangunan manusia, yang dapat dinilai dengan melihat seberapa besar permasalahan yang paling mendasar di masyarakat tersebut dapat teratasi.

\section{Deskripsi Responden}

Jenis kelamin dapat mencerminkan masyarakat dari kelompok mana yang dipandang dominan dalam kegiatan CSR perusahaan. Usia dapat mencerminkan masyarakat dari kelompok usia mana yang dipandang dominan sehingga akan dapat diambil rencana tindak atau program apa yang dapat dirancang untuk meningkatkan kepuasan masyarakat. Pekerjaan mempunyai peran penting dalam kehidupan fisik dan psikis seseorang. Status Menikah menunjukkan bahwa status dari masyarakat yang terikat dalam perkawinan pada saat pencacahan, baik tinggal bersama maupun terpisah. Pendidikan merupakan salah satu kebutuhan pokok setiap individu.

Tabel 1 Rekapitulasi Deskripsi Responden (Masyarakat) Terhadap Program CSR (Orang)

\begin{tabular}{|c|c|c|c|c|}
\hline No. & Uraian & $\begin{array}{c}\text { Kecamatan } \\
\text { Citereup } \\
\text { (PT Indocemet) }\end{array}$ & $\begin{array}{c}\text { Kecamatan } \\
\text { Klapanunggal } \\
\text { (PT Holcim) }\end{array}$ & $\begin{array}{c}\text { Kecamatan } \\
\text { Nanggung } \\
\text { (PT Antam) }\end{array}$ \\
\hline 1 & Jenis kelamin laki-laki & 73 & 38 & 70 \\
\hline 2 & Usia $41-55$ tahun & 32 & 41 & 29 \\
\hline 3 & Jenis pekerjaan wirausaha & 49 & 15 & 39 \\
\hline 4 & Status perkawinan menikah & 84 & 50 & 93 \\
\hline \multirow[t]{2}{*}{5} & $\begin{array}{l}\text { Tingkat pendidikan } \\
-\mathrm{SD}\end{array}$ & - & - & $\begin{array}{c}- \\
40\end{array}$ \\
\hline & - SMP & 46 & - & - \\
\hline \multirow[t]{5}{*}{6} & Pendapatan & & & \\
\hline & $\operatorname{Rp} 100.000-<\operatorname{Rp} 300.000$ & - & - & 27 \\
\hline & Rp. $300.000-<$ Rp. 500.000 & - & 27 & - \\
\hline & $\operatorname{Rp} 500.000->\operatorname{Rp} 700.000$ & & & 27 \\
\hline & $>\operatorname{Rp} 1.000 .000$ & 40 & - & - \\
\hline \multirow[t]{3}{*}{7} & $\begin{array}{l}\text { Pihak yang Mempengaruhi } \\
\text { Keterlibatan dalam CSR }\end{array}$ & & & \\
\hline & - Teman & 33 & - & - \\
\hline & - Ketua RT & - & 27 & 33 \\
\hline
\end{tabular}

Untuk menggambarkan kondisi ekonomi suatu keluarga, maka dapat dilihat dari tingkat pendapatannya. Pendapatan keluarga dapat digunakan untuk mengukur tingkat kesejahteraan keluarga. Keputusan yang diambil individu dapat terjadi karena adanya tarikan dari tuntutan lingkungan. Keterlibatan responden ikut serta dalam program CSR juga dipengaruhi oleh orang-orang di sekitarnya, seperti: teman, tetangga, dll. Adapun rekapitulasi deskripsi responden pada Tabel 1. 
Berdasarkan Tabel 1, dapat dilihat bahwa sebagian besar responden yang terlibat dalam kegiatan CSR berjenis kelamin laki-laki yang berarti sebagian besar program CSR membutuhkan tenaga laki-laki, seperti: pembangunan dan perbaikan sarana umum, dan pelatihan mekanik. Sebagian responden berusia antara 41-55 tahun yang berarti bahwa sebagian besar responden yang terlibat dalam kegiatan CSR berusia dewasa, sehingga memiliki kematangan dalam berpikir dan masih usia produktif.

Berdasarkan pekerjaan, sebagian besar responden bekerja sebagai wirausaha, sedangkan di Kecamatan Klapanunggal juga didominasi oleh petani, yang berarti bahwa sebagian besar responden dalam kegiatan CSR mempunyai waktu yang tidak terikat dengan waktu kerja formal karena wirausaha dan petani bisa mengatur waktu kerjanya sendiri. Sebagian besar responden berstatus menikah berarti sebagian besar responden mempunyai tanggung jawab yang besar, khususnya responden laki-laki.

$\begin{array}{ccc}\begin{array}{c}\text { Sebagian } \\ \text { berpendidikan }\end{array} & \text { besar } & \text { responden } \\ \text { SMP } & \text { (Kecamatan }\end{array}$ Citeureup) sedang di Kecamatan Klapanunggal dan Kecamatan Nanggung didominasi lulusan SD yang berarti bahwa tingkat pendidikan bukan menjadi syarat utama mengikuti program CSR. Berdasar pendapatan, sebagian besar responden berpendapatan > Rp.1.000.000,00 untuk Kecamatan Citeureup. Responden di Kecamatan Klapanunggal sebagian besar berpendapatan Rp. 300.000,00 - sampai dengan Rp. 500.000,00. Untuk Kecamatan Nanggung sebagian besar responden berpendapatan Rp. 100.000,00 - sampai dengan Rp. 300.000,00 dan Rp. $500.000,00$ - sampai dengan Rp. 700.000,00. Pendapatan responden di Kecamatan Klapanunggal dan Kecamatan Nanggung masih di bawah upah minimum propinsi yang rata-rata berkisar antara Rp.800.000 - Rp.900.000,00. Akibatnya responden di dua kecamatan tersebut memiliki keterbatasan dalam memenuhi kebutuhan dasar hidupnya.

Sebagian besar responden terlibat dalam program CSR perusahaan karena pengaruh dari teman (Kecamatan Citeureup), sedangkan Kecamatan Klapanunggal dan Kecamatan Nanggung didominasi oleh pengaruh Ketua RT (Rukun Tetangga). Hal ini menunjukkan bahwa teman dan ketua RT berperanan penting dalam menyebarluaskan informasi tentang program CSR perusahaan.

\section{Uji Asumsi Klasik (X Ke Y) dan (Y Ke} Z)

$\begin{array}{rrr}\text { Hasil pengujian asumsi } & \text { klasik } \\ \text { terhadap normalitas data, } & \text { uji }\end{array}$ multikolinieritas, uji heteroskedastisitas menunjukkan bahwa data bebas dari multikolinieritas dan heteroskedastisitas.

\section{Hasil Pengujian Regresi Berganda Model Penelitian}

Berdasarkan uji regresi berganda menunjukkan bahwa persepsi konsumen/masyarakat dan kepuasan konsumen/masyarakat berpengaruh terhadap CSR (persamaan 1). Sedangkan persamaan 2 menunjukkan pengaruh CSR yang terdiri dari: kesehatan, pendidikan, lingkungan, keinginan dan kebutuhan dasar manusia serta keselamatan terhadap sosial ekonomi masyarakat. Hasil analisis regresi dapat dilihat pada Lampiran 1.

Berdasarkan Lampiran 1, model regresi berganda yang digunakan dapat menjelaskan $70,90 \%$ dari variabel dependen. Secara keseluruhan model ini signifikan pada tingkat kepercayaan $95 \%$. (F-hitung 301,381) sehingga model ini cukup memadai untuk digunakan sebagai alat analisis. Secara parsial persepsi konsumen/masyarakat dan kepuasan konsumen/masyarakat berpengaruh terhadap CSR.

Sedangkan berdasarkan ringkasan hasil regresi berganda bahwa model yang digunakan dapat menjelaskan $62,20 \%$ dari variabel dependen. Secara keseluruhan model ini signifikan pada tingkat 
kepercayaan 95\%. (F-hitung 80,437) sehingga model ini cukup memadai untuk digunakan sebagai alat analisis. Secara parsial kesehatan, lingkungan, keinginan dan kebutuhan dasar manusia dan keselamatan berpengaruh terhadap sosial ekonomi masyarakat. Sedangkan pendidikan tidak berpengaruh terhadap sosial ekonomi masyarakat.

\section{Importance and Performance Analysis (IPA)}

Importance and Performance Analysis (IPA) digunakan sebagai penentu prioritas perbaikan yaitu dengan menggabungkan pengukuran faktor tingkat kepentingan dan tingkat kinerja dalam grafik yang memudahkan penjelasan data dan mendapatkan usulan praktis. Diagram IPA pada Tabel 2 adalah diagram IPA pada 5 (lima) program CSR berikut ini.

Tabel 2 Penilaian Program CSR dan Harapan Terhadap Program CSR

\begin{tabular}{lll}
\hline Variabel & $\begin{array}{l}\text { Penilaian CSR } \\
(\mathbf{X})\end{array}$ & $\begin{array}{l}\text { Harapan CSR } \\
(\mathbf{Y})\end{array}$ \\
\hline Pendidikan (A) & 3.524 & 4.564 \\
Kesehatan (B) & 3.464 & 4.590 \\
Lingkungan (C) & 3.460 & 4.782 \\
Keinginan dan Kebutuhan Dasar Manusia & 3.430 & 4.782 \\
(D) & & \\
Keamanan (E) & 3.570 & 4.564 \\
Total & $\mathbf{3 . 4 9}$ & $\mathbf{4 . 6 6}$ \\
\hline
\end{tabular}

Sumber: data primer diolah, 2012

Berdasarkan hasil perhitungan tersebut, nilai-nilai yang telah diperoleh kemudian dimasukkan ke dalam diagram IPA, di mana important merupakan kinerja CSR dan performance merupakan harapan CSR, seperti gambar berikut ini.

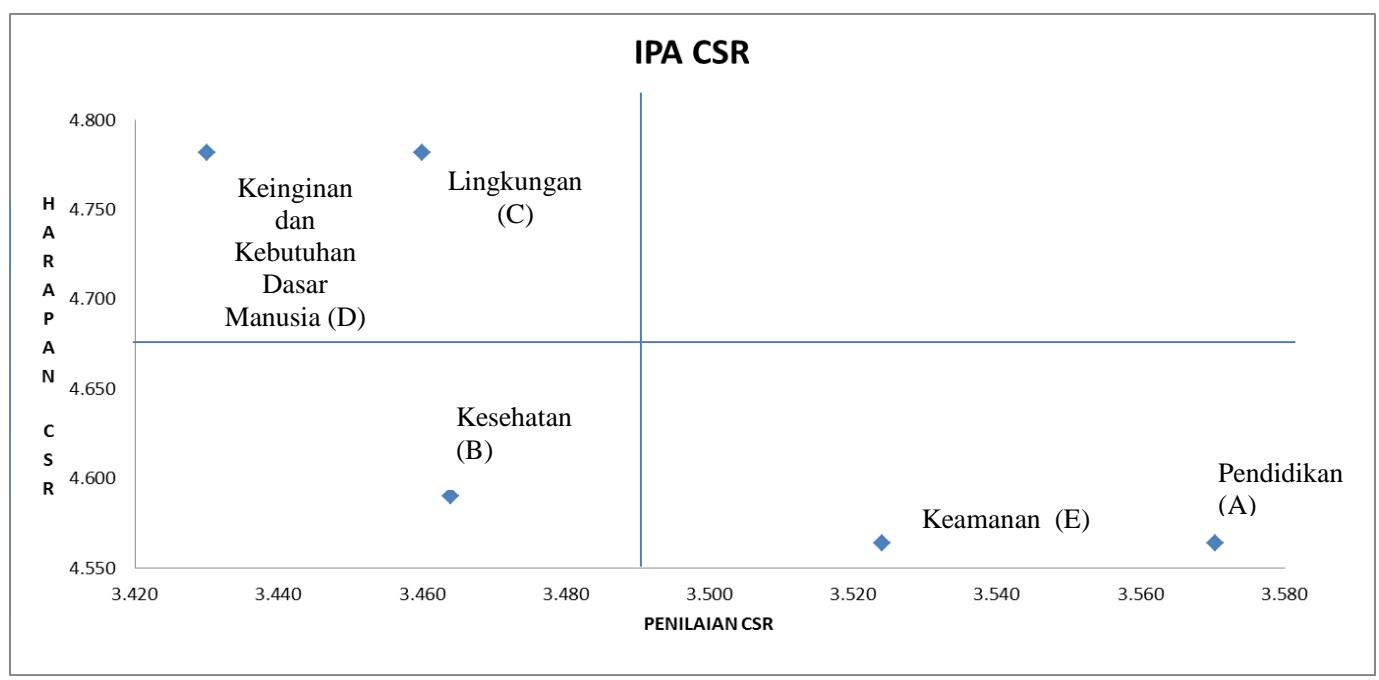

Gambar 5. Evaluasi atau Kinerja Program CSR

Berdasarkan Gambat 5 kinerja program CSR yang berada pada prioritas utama (kuadran A), kuadran ini memiliki tingkat kepentingan yang tinggi, namun dilihat dari tingkat kinerja dinilai rendah, sehingga semua indikator dalam kuadran ini harus meningkatkan kinerjanya agar lebih optimal untuk program CSR yaitu keinginan dan kebutuhan dasar manusia serta lingkungan. Hal ini didorong oleh beberapa faktor, diantaranya adalah kegiatan yang dilakukan oleh perusahaan 
tidak menerapkan konsep-konsep pengembangan masyarakat misalnya tidak sesuai dengan kebutuhan masyarakat dan tidak dapat meningkatkan partisipasi masyarakat untuk ikut menyukseskan program-program CSR tersebut. Faktor tersebut pada akhirnya menyebabkan pelaksanaan kegiatan CSR tidak mampu berkembang secara efektif untuk mencapai tujuannya, yakni memberdayakan masyarakat dan lingkungannya agar kesejahteraan itu tercapai (Rahmawati, 2010). Dalam lingkungan masyarakat, dunia usaha merupakan bagian dari komunitas yang memiliki tanggung jawab sosial terhadap seluruh pihak di sekitarnya. Hal tersebut sejalan dengan Khusnul (2009) mengemukakan bahwa CSR sebagai komitmen perusahaan atau dunia bisnis untuk berkontribusi dalam pengembangan ekonomi berkelanjutan dengan memperhatikan tanggungjawab sosial perusahaan dan menitikberatkan pada keseimbangan antara perhatian terhadap aspek ekonomi, sosial dan lingkungan. Dengan perkataan lain, Corporate Social Responsibility (CSR) bertujuan untuk mencapai keseimbangan antara mencetak keuntungan yang harus seiring dan berjalan selaras dengan fungsifungsi sosial dan pemeliharaan lingkungan hidup demi terwujudnya pembangunan yang berkelanjutan (Ambadar, 2008).

\section{Interpretasi Persepsi dan Kepuasan Masyarakat Terhadap CSR}

Pengaruh persepsi dan kepuasan masyarakat secara simultan maupun parsial terhadap CSR adalah: a) berdasarkan hasil perhitungan koefisien regresi, maka persepsi masyarakat dan kepuasan masyarakat mempunyai pengaruh terhadap CSR; b) berdasarkan hasil perhitungan koefisien korelasi, maka persepsi masyarakat dan kepuasan masyarakat mempunyai hubungan positif dan sangat kuat dengan CSR; c) berdasarkan uji hopotesis, persepsi masyarakat dan kepuasan masyarakat secara simultan berpengaruh nyata terhadap CSR dan masing-masing variabel (persepsi masyarakat dan kepuasan masyarakat) secara parsial juga berpengaruh terhadap CSR.

Persepsi masyarakat terhadap seluruh program CSR yang dilaksanakan oleh PT Indocement, PT Holcim dan PT Antam dapat memberikan manfaat kepada masyarakat. Dalam hal ini peran masyarakat sangat penting dalam menunjang keberlangsungan perusahaan. Pada sisi lain juga dapat dijelaskan bahwa, keberadaan perusahaan di suatu lingkungan masyarakat akan terasa nyaman dan tenang dalam kegiatan operasionalnya manakala masyarakat sekitar perusahaan bersifat kooperatif dengan perusahaan. Masyarakat peneriman manfaat program CSR merasa puas dengan kinerja program CSR yang dilakukan oleh PT Indocement, PT Holcim dan PT Antam. Oleh karena itulah peranan CSR perusahaan sangat penting manakala perusahaan masih tetap ingin menjalankan fungsi bisnisnya dan harapan masyarakat sekitarnya yang menjadi sasaran programnya.

\section{Interpretasi CSR Terhadap Sosial Ekonomi Masyarakat}

Pengaruh CSR baik secara simultan maupun parsial terhadap aspek sosial ekonomi masyarakat kasus Kabupaten Bogor adalah: a) berdasarkan hasil perhitungan koefisien regresi, kegiatan CSR bidang pendidikan, kesehatan, lingkungan, kenaikan keinginan dan kebutuhan dasar manusia dan keamanan mempunyai pengaruh terhadap sosial ekonomi masyarakat; b) berdasarkan hasil perhitungan koefisien korelasi, kegiatan CSR bidang pendidikan, kesehatan, lingkungan, kenaikan keinginan dan kebutuhan dasar manusia dan keamanan mempunyai hubungan positif dan kuat dengan sosial ekonomi masyarakat; c) berdasarkan uji hopotesis, kegiatan CSR bidang pendidikan, kesehatan, lingkungan, kenaikan keinginan dan kebutuhan dasar manusia 
dan keamanan berpengaruh secara nyata terhadap sosial ekonomi masyarakat.

Secara parsial, kegiatan CSR bidang pendidikan tidak berpengaruh terhadap sosial ekonomi masyarakat. Program CSR dilakukan membantu pemerintah memperbaiki Indeks Pembangunan Manusia (IPM) Indonesia, melalui pelaksanaan program-program yang membantu pencapaian target pembangunan millenium atau Millenium Development Goals (MDGs) serta membangun hubungan yang harmonis dan kondusif dengan semua pemangku kepentingan (stakeholder) untuk mendukung pencapaian tujuan korporasi terutama dalam membangun reputasi korporasi. Sedangkan kegiatan CSR bidang pendidikan tidak berpengaruh secara nyata terhadap sosial ekonomi masyarakat, hal ini disebabkan bahwa pemerintah juga memberikan pelayanan kepada masyarakat dalam bentuk pendidikan selama 9 tahun sesuai dengan UUD 1945 yaitu mencerdaskan bangsa dan adanya dana Bos diberikan kepada sekolah-sekolah seluruh masyarakat tidak mampu yang membutuhkan pendidikan bertujuan agar tidak ada lagi kesenjangan dalam hal mendapatkan pendidikan. Tidak sepenuhnya menjadi tanggung jawab CSR dan bantuan pendidikan hanya diberikan pada masyarakat disekitar perusahaan.

Menurut Edi Suharto (2010) bahwa program CSR bidang pendidikan sebagai salah satu pilar pembangunan bangsa pendidikan tidak bisa diabaikan oleh perusahaan menerapkan CSR pendidikan adalah bidang yang ada dalam implementasi CSR seperti memberikan beasiswa, pengadaan bantuan tenaga pengajar, pengadaan peralatan penunjang pendidikan dan lain sebagainya. Padahal sesuai dengan UU yang ada, keberadaan CSR melekat secara inherent dengan manajemen perusahaan, sehingga bidang kegiatan dalam CSR pun masih dalam kontrol manajemen perusahaan (Freemand, 1984). Lebih jauh lagi dalam lingkungan bisnis perusahaan, masyarakat di sekitar perusahaan pada dasarnya merupakan pihak yang perlu mendapatkan apresiasi. Apresiasi ini dapat diwujudkan dalam bentuk peningkatan kesejahteraan hidup mereka melalui kegiatan pemberdayaan masyarakat yang dilakukan oleh kegiatan CSR perusahaan. Hal ini karena perusahaan dan masyarakat pada dasarnya merupakan kesatuan elemen yang dapat menjaga keberlangsungan perusahaan itu sendiri.

\section{Efektivitas Implementasi Program CSR}

Sebagaimana diketahui, tanggung jawab sosial perusahaan atau corporate social responsibility (CSR) merupakan bentuk nyata kepedulian kalangan dunia usaha terhadap lingkungan di sekitarnya. CSR merupakan bentuk praktek bisnis yang transparan yang berlandaskan pada nilai etika, ketaatan hukum, dan penghargaan pada manusia, komunitas, dan lingkungan. Dengan kata lain, CSR menunjukkan bentuk akuntabilitas publik sektor bisnis yang tidak hanya terbatas pada akuntabilitas ekonomis kepada konsumen, karyawan dan pemegang saham saja, tapi juga tanggung jawab sosial perusahaan terhadap komunitas dan lingkungannya.

Berbagai sektor dibidik dalam kegiatan CSR, seperti pendidikan, kesehatan, ekonomi, lingkungan dan bahkan sosial budaya. Mengingat pentingnya peranan program CSR dalam membantu pemerintah dalam mengurangi tingkat kemiskinan dan pengangguran, maka program CSR perlu dikelola dengan baik dan berkesinambungan. agar masyarakat bisa merasakan hasil yang maksimal dari kegiatan CSR. Menurut Yanti T. Koestoer (2007), bahwa tidak semua perusahaan mempunyai komitmen kuat untuk melaksanakan CSR yang baik. Banyak perusahaan yang melihat CSR sekedar sebagai "kosmetik" untuk mendapatkan legitimasi yang dapat mempengaruhi opini publik terhadap perusahaan. Untuk perusahaan yang berorientasi mencari keuntungan, hakekat 
CSR yang sukarela ditambah dengan lemahnya penegakan hukum di Indonesia membuat mereka mudah untuk menghindari keharusan melaksanakan CSR. Berapa pun besarnya CSR yang mereka salurkan untuk menyokong pembangunan komunitas, tetap saja ada protes, boikot, ataupun ancaman fisik yang menempatkan perusahaan pada situasi dilematis. Sedangkan program CSR berikut ini:

Tabel 4. Program CSR PT Indocement, PT Holcim dan PT Antam

\begin{tabular}{|c|c|c|c|c|}
\hline No. & $\begin{array}{l}\text { Bidang } \\
\text { Kegiatan CSR }\end{array}$ & $\begin{array}{l}\text { Efektivitas Program CSR } \\
\text { PT Indocement }\end{array}$ & $\begin{array}{l}\text { Efektivitas Program CSR } \\
\text { PT Holcim }\end{array}$ & $\begin{array}{l}\text { Efektivitas Program CSR PT } \\
\text { Antam }\end{array}$ \\
\hline 1. & Pendidikan & $\begin{array}{l}\text { Membantu orangtua yang } \\
\text { kurang mampu membiayai } \\
\text { biaya sekolah anaknya }\end{array}$ & $\begin{array}{lr}\text { Kualitas } & \text { pendidikan } \\
\text { meningkat; } & \text { sebagian } \\
\text { masyarakat } & \text { punya } \\
\text { ketrampilan untuk usaha } & \\
\text { secara mandiri, misalnya } \\
\text { usaha sablon }\end{array}$ & $\begin{array}{l}\text { Membantu masyarakat } \\
\text { kurang mampu } \\
\text { menyekolahkan } 1 \text { (satu) } \\
\text { Desa/orang menjadi bidan }\end{array}$ \\
\hline 2. & Kesehatan & $\begin{array}{lr}\text { Meningkatnya } & \text { kualitas } \\
\text { kesehatan masyarakat dan } \\
\text { pengetahuan } \\
\text { kesehatan }\end{array}$ & $\begin{array}{l}\text { Kualitas kesehatan balita } \\
\text { dan ibu hamil meningkat }\end{array}$ & $\begin{array}{l}\text { Membantu masyarakat } \\
\text { kurang mampu untuk berobat }\end{array}$ \\
\hline 3. & Lingkungan & $\begin{array}{l}\text { Terjaganya } \\
\text { lingkungan desa } \\
\text { perusahaan dan di dalam } \\
\text { perusahaan }\end{array}$ & $\begin{array}{l}\text { a. Masyarakat dapat } \\
\text { meningkatkan pendapatannya } \\
\text { b. Reputasi } \\
\text { perusahaan makin baik }\end{array}$ & $\begin{array}{l}\text { Memberikan penghijauan } \\
\text { pada masyarakat }\end{array}$ \\
\hline 4. & $\begin{array}{l}\text { Keinginan dan } \\
\text { Kebutuhan } \\
\text { Dasar Manusia }\end{array}$ & $\begin{array}{l}\text { 1. Masyarakat dapat } \\
\text { menjalin kebersamaan } \\
\text { dengan berkumpul dan } \\
\text { bersosialisasi di gedung } \\
\text { pertemuan } \\
2 . \quad \text { Masyarakat } \\
\text { mampu melakukan } \\
\text { kegiatan sosial dan budaya } \\
\text { termasuk tari, musik dan } \\
\text { seni Masyarakat } \\
3 . \quad \text { mempunyai rumah layak } \\
\text { huni }\end{array}$ & $\begin{array}{l}\text { 1. Terbinanya } \\
\text { hubungan baik antara } \\
\text { perusahaan dan masyarakat } \\
\text { 2. Peningkatan kualitas } \\
\text { hidup masyarakat sekitar }\end{array}$ & $\begin{array}{l}\text { Adanya kegiatan agama dan } \\
\text { meningkatkan pendidikan } \\
\text { jasmani }\end{array}$ \\
\hline 5. & Keamanan & $\begin{array}{l}\text { Terjaganya } \\
\text { lingkungan desa } \\
\text { perusahaan dan di dalam } \\
\text { perusahaan }\end{array}$ & $\begin{array}{l}\text { 1. Terjalinnya } \\
\text { silaturahmi yang baik antara } \\
\text { para pemangku kepentingan } \\
\text { 2. Reputasi perusahaan } \\
\text { makin baik di } \\
\text { masyarakat } \\
\text { 3. Terjaga } \\
\text { lingkungan } \\
\text { perusahaan }\end{array}$ & $\begin{array}{l}\text { Tidak terjadi kerusuhan CSR } \\
\text { memberikan dampak positif }\end{array}$ \\
\hline
\end{tabular}

Sumber: Hasil Wawancara Pelasanaan CSR PT Indocement, PT Holcim, PT Antam, 2012

Program CSR PT Indocement, PT Holcim dan PT Antam dirancang untuk memenuhi kebutuhan masyarakat dengan strata ssosial yang berbeda. Dalam prakteknya, sebagian kegiatan CSR berupaya melibatkan dan memberikan manfaat bagi sebagian besar anggota masyarakat yang kurang mendapatkan kesempatan dan kegiatan lainnya dirujukan untuk mengembangkan masyarakat yang berpotensi. Pelaksanaan program CSR perusahaan di Kabupaten 
Bogor telah membantu meringnkan tugas pemerintah dalam ikut pemberdayaan ekonomi masyarakat miskin dan meningkatkan kualitas pemuda putus sekolah serta mengurangi tingkat pengangguran. Hal ini diwujudkan dengan terbukanya kesempatan usaha dan kesempatan bekerja dalam berbagai bidang seperti sablon, membuat makanan kripik, bengkel sepeda motor, kerajinan sampah plastik dan kertas, dan lain sebagainya.

\section{Interprestasi Penilaian Masyarakat dan Harapan Masyarakat Terhadap CSR}

Perusahaan dan masyarakat pada dasarnya merupakan kesatuan elemen yang dapat menjaga keberlangsungan perusahaan itu sendiri. Lebih jauh lagi dalam lingkungan bisnis perusahaan, masyarakat disekitar perusahaan pada dasarnya merupakan pihak yang perlu mendapatkan apresiasi. Apresiasi ini dapat diwujudkan dalam bentuk peningkatan kondisi sosial ekonomi mereka melalui kegiatan pemberdayaan masyarakat yang dilakukan oleh kegiatan CSR perusahaan. Implementasi CSR merupakan perwujudan komitmen yang dibangun oleh perusahaan yang bertujuan untuk memberikan kontribusi pada peningkatan kualitas kehidupan masyarakat. Tanggung jawab sosial perusahaan tersebut dapat dikatakan sebagai timbal balik perusahaan kepada masyarakat dan lingkungan sekitarnya karena perusahaan telah mengambil keuntungan atas masyarakat dan lingkungan sekitarnya (Susiloadi, 2008).

Salah satu aturan dasar dari pemerintah Indonesia yang membuat konsep CSR tersebut harus direalisasikan dan diimplementasikan oleh setiap perusahaan di Indonesia karena diberlakukannya Undang-Undang tentang Perseroan Terbatas (UU-PT) yang salah satu pasal dalam UU-PT 2007 tersebut, yakni dalam pasal 74 ayat 1, disebutkan bahwa setiap perseroan yang menjalankan kegiatan usaha yang berkaitan dengan pengelolaan sumber daya alam diwajibkan untuk melaksanakan kegiatan tanggung jawab sosial dan lingkungan. Berdasarkan Undang-Undang tersebut, setiap perusahaan kini wajib mengeluarkan dana perusahaan untuk mengimplementasikan dan membuat program CSR yang ditujukan bagi seluruh stakeholder terkait.

Bentuk tanggung jawab sosial perusahaan dapat dijelaskan melalui berbagai bentuk aktivitas perusahaan seperti program pembangunan atau pengembangan komunitas, pelayanan komunitas, dan pemberdayaan komunitas. Beberapa perusahaan besar telah mampu mengembangkan bentuk-bentuk kegiatan CSR-nya dengan baik melalui berbagai macam program. Dalam konsep pengembangan masyarakat, keberhasilan suatu program dapat diukur dari sejauhmana program tersebut telah sesuai dengan kebutuhan masyarakat, menggunakan kealihan dari luar yang diperlukan (pendampingan), dan bersifat partisipatif. Ketika suatu program CSR dapat diinisiasikan berdasarkan prinsipprinsip pengembangan masyarakat tersebut maka program tersebut diharapkan mencapai keberhasilan sehingga memberikan manfaat berarti bagi masyarakat. Hal tersebut tentunya memberikan dampak yang lebih positif dalam kehidupan masyarakat khususnya dalam kondisi sosial ekonomi mereka.

Indikator yang dipergunakan untuk mengukur keberhasilan implementasi konsep Corporate Social Responsibility adalah partisipasi dari seluruh komunitas yang ada dan keberlanjutan pola kehidupan masyarakat yang bersangkutan (Setiawan dalam Anggraeni 2013). Dalam konsep pengembangan masyarakat, keberhasilan suatu program CSR dapat dinilai dari sejauh mana program tersebut diinisiasikan berdasarkan prinsip-prinsip pengembangan masyarakat.

Jim Ife dan Longman dalam Nasdian (2006) menjelaskan bahwa terdapat dua puluh dua prinsip pengembangan masyarakat. Prinsip-prinsip tersebut yakni pembangunan secara terpadu, 
mengembangkan proses untuk melawan ketimpangan struktural, memahami dan berkomitmen terhadap hak-hak asasi manusia, berkelanjutan, memiliki tujuan dan strategi pemberdayaan, menghubungkan antara persoalan individu dengan struktural, mengembangkan keswadayaan masyarakat, independensi dari negara, memiliki tujuan jangka menengah dan visi ideal, berdasarkan inisiatif dan potensi pengembangan yang tumbuh dari masyarakat sendiri, berdasarkan pada langkah-langkah pengembangan, memperkuat kesatuan masyarakat, menggunakan keahlian dari luar yang diperlukan, mengembangkan kepemilikan masyarakat, menggunakan pendekatan proses dan hasil yang selaras dengan tujuan, anti kekerasan, bersifat inklusif, berdasarkan konsensus dalam pengambilan keputusan, mengembangkan kerjasama, partisipatif, merumuskan dan menyepakati "kebutuhan" secara bersama.

\section{Strategi Program CSR untuk Peningkatan Kepuasan Masyarakat}

Strategi yang dapat diterapkan program CSR sesuai dengan diagram IPA adalah sebagai berikut: 1) Prioritas utama (kuadran A), menunjukan suatu kinerja yang dianggap mempengaruhi kepuasan, termasuk unsur persepsi masyarakat yang dianggap penting oleh masyarakat, namun program CSR dianggap belum melaksanakan sesuai keinginan masyarakat, hal ini mengakibatkan masyarakat merasa kecewa. Strategi perbaikan yang dapat dilakukan oleh program CSR dengan memperhatikan keinginan dan kebutuhan dasar manusia serta lingkungan diharapkan dapat meningkatkan keberdayaan masyarakat sehingga memberikan manfaat kepada seluruh pihak khususnya masyarakat sendiri dalam meningkatkan kondisi sosial ekonomi mereka menjadi lebih sejahtera. CSR merupakan wujud kepedulian perusahaan terhadap ekonomi, sosial, dan lingkungan yang di dasari tiga prinsip dasar yang meliputi profit, people dan planet (3P). Profit, sebagai lembaga usaha dengan profit oriented, perusahaan tetap harus berorientasi untuk mencari keuntungan ekonomi untuk menjamin kelangsungan hidup perusahaan sehingga perusahaan dapat terus beroperasi dan berkembang. People, untuk menjamin kelangsungan hidup dan meningkatkan daya saing perusahaan, perusahaan harus memiliki kepedulian terhadap kesejahteraan karyawan dan manusia yang merupakan aset berharga dalam organisasi maupun negara.

Wujud program CSR yang berorientasi sosial (people) adalah pemberian beasiswa bagi pelajar sekitar perusahaan, pendirian sarana pendidikan dan kesehatan, pemberian bantuan modal usaha mikro. Planet, kepedulian terhadap lingkungan hidup dan keberlanjutan keragaman hayati bisa dilakukan melalui pelaksanaan program penghijauan. Ketiga faktor ini saling berkaitan erat satu sama lain dan bersifat dinamis tergantung kondisi dan tekanan sosial, politik, ekonomi dan lingkungan, serta kemungkinan adanya konflik kepentingan antar berbagai pihak yang dapat mempengaruhi program CSR; 2) Prioritas rendah (kuadran $\mathrm{C}$ ), menunjukan faktor persepsi masyarakat yang diberikan oleh program CSR kurang penting bagi masyarakat dan kinerja program CSR dinilai kurang baik oleh masyarakat.

Program CSR yang berada di kuadaran $\mathrm{C}$ adalah: kesehatan karena CSR sebagai bentuk kegiatan yang dilakukan oleh suatu perusahaan untuk meningkatkan kualitas kehidupan masyarakat disekitarnya melalui program kesehatan agar tercapai keseimbangan antara keuntungan ekonomi, kesejahteraan masyarakat dan kelestarian lingkungan hidup; Sedang yang 3) Prioritas berlebihan (kuadran D), menunjukan faktor persepsi masyarakat yang dianggap kurang penting oleh masyarakat, namun kinerja yang diberikan program CSR memuaskan masyarakat. Program CSR yang berada di kuadran $\mathrm{D}$ adalah keamanan dan 
pendidikan. Masyarakat merupakan pihak yang akan sangat berpengaruh terhadap keberlangsungan suatu perusahaan, sehingga sangat erat kaitannya antara pelaksanaan program CSR oleh perusahaan-perusahaan, dan berkontribusi (berdampak) dalam peningkatan kesejahteraan masyarakat sekitarnya.

\section{KESIMPULAN DAN IMPLIKASI KEBIJAKAN}

\section{Kesimpulan}

Berdasarkan hasil penelitian dan pembahasan disimpulkan sebagaimana berikut ini:

1) Secara simultan dan parsial persepsi konsumen/masyarakat dan kepuasan konsumen/masyarakat berpengaruh terhadap CSR. Secara simultan kesehatan, lingkungan, keinginan dan kebutuhan dasar manusia dan keselamatan berpengaruh terhadap social ekonomi masyarakat. Sedangkan pendidikan tidak berpengaruh terhadap sosial ekonomi masyarakat;

2) Efektivitas implementasi dari programprogram CSR yang diberikan perusahaan di lapangan, kasus Kabupaten Bogor sudah cukup efektif. Sebagaimana ditunjukkan dengan besarnya manfaat bagi peserta program CSR, khususnya di bidang pendidikan, kesehatan, ekonomi, sosialbudaya-agama dan keamanan serta lingkungan;

3) Pelaksanaan program CSR perusahaan di Kabupaten Bogor telah membantu meringankan tugas pemerintah dalam ikut pemberdayaan ekonomi masyarakat miskin dan mengurangi tingkat pengangguran;

4) Secara keseluruhan program CSR belum sesuai harapan masyarakat seperti keinginan dan kebutuhan serta lingkungan berdasar diagram IPA perlu mendapat perhatian khusus;

5) Untuk meningkatkan kinerja program CSR diperlukan strategi sesuai dengan diagram IPA, strategi tersebut diantaranya:

a) melakukan perbaikan secara terus- menerus sehingga performance atribut (harapan CSR) yang ada dalam kuadran ini akan meningkat; b) mempertahankan secara terus menerus agar selalu berada pada kuadran ini dan tidak menurun kinerjanya; mengevaluasi/mempertimbangkan kembali peningkatannya, namun dengan tidak menghilangkan indikatornya, karena biasanya kekecewaan masyarakat berawal dari kuadran ini; d) mengevaluasi seluruh kegiatan yang berlebihan, sehingga didapatkan bagian-bagian yang harus dipertahankan dan bagian-bagian yang harus dikurangi; dan

6) Penelitian persepsi dan kepuasan masyarakat terhadap CSR dan dampaknya terhadap sosial ekonomi masyarakat dengan menggunakan analisa statistik secara deskriptif, pada umumnya memiliki keterbatasan karena berhenti pada apakah kinerja program CSR sudah sesuai dengan harapan masyarakat dengan pengukuran baik, tidak baik atau puas, tidak puas.

\section{Implikasi Kebijakan}

berikut ini:

Adapun saran yang diberikan

1) Pelaksanaan program CSR perusahaan di lingkungan sekitar operasi perusahaan perlu didorong lebih kuat dalam rangka meningkatkan partisipasi perusahaan membantu pemerintah untuk meningkatkan pemberdayaan masyarakat dan mengentaskan kemiskinan. Hal ini mengingat bahwa program CSR memberikan manfaat yang cukup besar bagi masyarakat yang mengikuti program CSR, terutama di bidang pendidikan. ekonomi, lingkungan dan keamanan;

2) Dalam melaksanakan program CSR, persepsi masyarakat kepuasan masyarakat perlu menjadi pertimbangan dalam penyusunan kebijakan CSR perusahaan karena persepsi masyaraat dan kepuasan masyarakat berpengaruh positif pada pelaksanaan CSR. Dengan makin baiknya persepsi masyarakat dan meningkatnya kepuasan masyarakat, maka pelaksanaan CSR diduga menjadi semakin baik, karena 
partisipasi masyarakat makin baik kualitasnya;

3) Peranan perusahaan semakin penting, khususnya dalam program pemberdayaan ekonomi masyarakat kurang mampu, sehingga dalam jangka waktu yang akan datang perlu ditingkatkan; dan

4) Bagi peneliti lain untuk melakukan penelitian secara kualitatif yang lebih mendalam dengan berusaha membahas secara detail program CSR untuk itu disarankan bagi peneliti lain untuk melakukan penelitian secara kualitatif kenapa hal tersebut terjadi.

\section{DAFTAR REFERENSI}

Agung Abdul Rasul dan Nurlaelah, 2010. Praktikum Statistika Ekonomi dan Bisnis dengan SPSS. Jakarta. Penerbit Mitra Wacana Media.

Arikunto, Suharsimi, (2006). Prosedur Penelitian, Suatu Pendekatan Praktis, Edisi Revisi. Jakarta. Penerbit PT. Bina Aksara.

Azwar, Saifuddin, 1997. Reliabilitas dan Validitas. Edisi Ke 3. Yogyakarta. Pustaka Pelajar.

Anggraeni, YD. 2013. Tingkat Keberhasilan Program Corporate Social Responsibility "Water Access Sanitation and Hygiene" PT Aqua Golden Mississippi Citereup. Skripsi. [Internet]. [diunduh 29 November 2013]. Dapat diunduh dari: http://repository.ipb.ac.id/handle/1234 $\underline{56789 / 66073}$

Bukhari Alma, 2003. Manajemen Pemasaran dan Pemasaran Jasa, Cetakan kelima, Bandung: Penerbit Alfabeta.

Badan Perencanaan Pembangunan Nasional. 2004

Chappe, W, \& Moon J. 2005. Corporate Social Responsibility (CSR) in Asia: A Seven-

Country Study of CSR web site Reporting Business Society.

Darmadi Durianto, Sugiarto, Toni Sitinjak, 2001. Strategi Menaklukan Pasar Melalui Riset

Ekuitas dan
Prilaku Merek. Jakarta. PT.Gramedia Pustaka Utama.

Edi Suharto, 2010. CSR \& Comdev Investasi Kreatif Perusahaan di Era Globalisasi. Bandung: Penerbit Alfabeta.

Freemand, R.E. 1984. Strategic Management: A Stakeholder Approach. Boston, MA: Pitman.

Husein Umar, 2008. Metode Penelitian. Jakarta. Raja Grafindo Persada.

Jajal \& Kurniawan, Fajar. 2012. Tanggung Jawab Sosial Perusahaan, ISO 26000: 2010 dan Peran Pemerintah. http:/csrindonesia.com/ (diakses 21 Juni 2010)

Kotler, Philip. 2002. Manajemen Pemasaran, Edisi Millenium Jilid 1. Jakarta: PT Prenhallindo. Kotler, Philip. 2000, Rethinking Marketing. Jakarta. Penerbit PT Gramedia Pustaka Utama.

Kotler, Philip \& Nancy Lee.2005. Corporate Social Responsibility: Doing the Most Good for Your Company and Your Cause. USA. John Wiley \& Sons Inc.

Khusnul, Emma. 2009. Program Pemberdayaan CSR Exxonmobil Dalam Peningkatan Kesejahteraan Sosial di Desa Gayam Kecamatan Gayam Kabupaten Bojonegoro. Jurnal Trunojoyo. [Internet]. [diunduh 11 November 2013]. 11(2). Dapat diunduh dari: http://pta.trunojoyo.ac.id/uploads/jour nals/090521100016/090521100016.pd $\underline{\mathrm{f}}$

M. Natsir, 2003. Metode Penelitian. Jakarta. Ghalia Indonesia.

Nasdian, Fredian Tonny. 2006. "Pengembangan Masyarakat (Community Development)". Bogor: Bagian Sosiologi Pedesaan dan Pengembangan Masyarakat Departemen Komunikasi dan Pengembangan Masyarakat Institut Pertanian Bogor

Prayogo, Dody. 2008. Corporate Social Responsibility, Social Justice, dan 
Distributive

Welfare

dalam Industri Tambang dan Migas di Indonesia dalam Jurnal Galang, Vol. 3 No. 3, Desember 2008. PIRAC.

Reza Rahman. 2009. Corporate Social Responsibility Antara Teori dan Kenyataan. Jakarta: Med Press (Anggota IKAPI).

Robbins, Stephen, 2006. Perilaku Organisasi. Jakarta. PT Indeks. Kelompok Gramedia.

Rangkuti. F., 2003. Measuring Customer Satisfaction : Tehnik Mengukur dan Srategi Meningkatkian Kepuasan Pelanggan. Jakarta. PT Gramedia Pustaka Utama.

Rahmawati A.2010. Efektivitas Organisasi dan Implementasi Program Corporate Social Responsibility PT. Indocement Tunggal Prakarsa Tbk. [Skripsi]. Bogor [ID]: Institut Pertanian Bogor.

Rosika, AA. 2011. Efektivitas dan Dampak Program Community Based Development Bali Sejahtera dalam Peningkatan Kesempatan Kerja dan Pendapatan Rumah Tangga Miskin di Kabupaten Gianyar. [Internet]. [diunduh 20 Maret 2014]. Dapat diunduh

dari:http://www.pps.unud.ac.id/thesis/ pdf thesis/unud-283-1379376497bab\%20i,ii,iii,iv.pdf.

Riduwan, 2005. Skala Pengukuran Variabel-Variabel Penelitian. Bandung Alfabeta.
Sunarto et. al., 2009. Metode Penelitian. Yogyakarta. BPC.

Sugiyono, 2004. Statistika Untuk Penelitian, Cetakan kelima, Penerbit CV. Alfabeta.

Sudjana, 1996. Metode Statistika. Bandung: Tarsito.

Sutisna. 2003. "Perilaku Konsumen/Masyarakat \& Komunikasi Pemasaran". Bandung: PT Remaja Rosdakaarya.

Suprananto, J., 2001. Pengukuran Tingkat Kepuasan Pelanggan Untuk Menaikkan Pangsa Pasar. Jakarta. Rineka Cipta.

Susiloadi, Priyanto. 2008. Implementasi Corporate Social Responsibility untuk Mendukung Pembangunan Berkelanjutan. Jurnal Spirit Publik. [Internet]. [diunduh 13 November 2013]. 04(2). Dapat diunduh dari: http://fisip.uns.ac.id/publikasi/sp4_2 priyanto.pdf

Undang-Undang Nomor 40 Tahun 2007 Tentang Perseroan Terbatas

Yanti Triwadiantini Koestoer, 2007, “ Corporate Social Responsibility in Indonesia Building Internal Corporate Values to Address Challenges in CSR Implementation", diunduh dari www.aseanfoundation.org, bulan Agustus 2012

Wahyudi, Isa dan Busyeri, Azhari. 2008. CSR: Prinsip, Pengaturan dan Implementasi. Intrans Publishing. 
Lampiran 1 Rangkuman Hasil Perhitungan Analisis Regresi Berganda Model Penelitian

\begin{tabular}{|c|c|c|c|c|c|c|c|c|c|}
\hline \multicolumn{5}{|c|}{ Hasil Estimasi Persamaan Regresi Ke -1 } & \multicolumn{5}{|c|}{ Hasil Estimasi Persamaan Regresi Ke -2 } \\
\hline Variabel & $\mathrm{B}$ & $\mathrm{t}$ hitung & Sig t & Beta & Variabel & $\mathrm{B}$ & t hitung & Sig t & Sig t \\
\hline Constant & 5,050 & 4,526 & 0,000 & & Constant & $-1,297$ & $-0,451$ & 0,652 & \\
\hline Persepsi & 0,287 & 8,609 & 0,000 & 0,375 & Kesehatan $\left(\mathrm{Y}_{1}\right)$ & 1,541 & 4,515 & 0,000 & 0,285 \\
\hline $\begin{array}{l}\text { Konsumen/ } \\
\text { Masyarakat }\left(\mathrm{X}_{1}\right)\end{array}$ & & & & & & & & & \\
\hline $\begin{array}{l}\text { Kepuasan } \\
\text { Konsumen/ } \\
\text { Masyarakat }\left(\mathrm{X}_{2}\right)\end{array}$ & 0,532 & 12,831 & 0,000 & 0,041 & Pendidikan $\left(\mathrm{Y}_{2}\right)$ & 0,265 & 0,801 & 0,424 & 0,054 \\
\hline $\mathrm{t}$ tabel & 1,6449 & & & & Lingkungan $\left(\mathrm{Y}_{3}\right)$ & 1,899 & 6,316 & 0,000 & 0,391 \\
\hline $\mathrm{R}$ & 0,842 & & & & $\begin{array}{lr}\text { Keinginan } & \text { dan } \\
\text { Kebutuhan } & \text { Dasar } \\
\text { Manusia }\left(\mathrm{Y}_{4}\right) & \end{array}$ & 1,983 & 2,858 & 0,005 & 0,117 \\
\hline R Square & 0,709 & & & & Keselamatan $\left(\mathrm{Y}_{5}\right)$ & 0,713 & 1,989 & 0,048 & 0,123 \\
\hline Adjusted R Square & 0,707 & & & & $\mathrm{t}$ tabel & $=1,6449$ & & & \\
\hline F hitung & 301,381 & & & & $\mathrm{R}$ & $=0,789$ & & & \\
\hline F tabel & 3,00 & & & & R Square & $=0,622$ & & & \\
\hline Sig F & 0,000 & & & & Adjusted R Square & $=0,615$ & & & \\
\hline SEE & 3,162 & & & & F hitung & $=80,437$ & & & \\
\hline & & & & & F tabel & $=2,21$ & & & \\
\hline & & & & & Sig F & $=0,000$ & & & \\
\hline & & & & & SEE & $=4,842$ & & & \\
\hline
\end{tabular}

Sumber: Data primer yang diolah, 2012 